ФОРМУВАННЯ ТОЛЕРАНТНОСТІ МАЙБУТНІХ СОЦІАЛЬНИХ ПРАЦІВНИКІВ У ПРОЦЕСІ ПРАКТИЧНОЇ ПІДГОТОВКИ

\title{
THE FORMING OF TOLERANCE FUTURE SOCIAL WORKERS IN THE PROCESS OF PRACTICAL PREPARATION
}

\begin{abstract}
На сучасному етапі розвитку нашої країни інсрраструктура просресійної діяльності соціального працівника $є$ доволі розгалуженою. Вона включає такі соціальні установи, як: департамент соціального захисту населення; територіальний центр соціального обслуговування пенсіонерів та одиноких непрацездатних громадян; будинок-інтернат для громадян похилого віку та інвалідів; геріатричний пансіонат, пансіонат для ветеранів війни і праці; чентр соціальних служб для сім'ї, дітей та молоді; соціальний центр матері та дитини; служба у справах дітей; центр соціально-психологічної реабілітації дітей; чентр соціально-психологічної реабілітації дітей та молоді з функціональними обмеженнями; центр соціально-психологічної допомоги; чентр професійної реабілітації інвалідів; центр реінтеграціі бездомних громадян; чентр учасників бойових дій; чентр зайнятості; пенсійний фронд mощо.

Відповідно, клієнтами соціального працівника є: dimu-сuроти та діти, позбавлені батьківського піклування; діти з інвалідністю; діти загиблих батьків під час виконання службових обов'язків; багатодітні, неповні, прийомні, малозабезпечені, неблагополучні сімї; трудові мігранти; безробітні; учасники бойових дій; внутрішньо переміщені особи; пенсіонери та одинокі непрацездатні громадяни тощо.

Зважаючи на обширний спектр установ та клієнтів, з якими може працювати соціальний працівник, одним із завдань вищого навчального закладу освіти $\epsilon$ формування у майбутніх срахівців толерантності як професійно важливої якості, що відображає активну соціальну позицію та психологічну готовність до налагодження позитивної взаємодії з людьми або групами іншого соціального, релігійного, національного середовища, інших поглядів, стилів мислення та поведінки.

3 огляду на зазначене у статmі розглядається модель формування толерантності майбутніх соціальних працівників у процесі їхньої практичної підготовки.

Ключові слова: толерантність, професійне становлення соціальних працівників,
\end{abstract}

модель фрормування толерантності, практична підготовка майбутніх соціальних працівників.

On the modern stage of the development of our country an infrastructure of professional activity of social worker is ramified enough. It includes such social establishments, as: department of social defence of population; territorial center of social maintenance of pensioners and single disabled citizens; house-boarding-school for senior citizens and invalids; geriatrics resort hotel, resort hotel for veterans of war and labor; a center of social services for family, children and young people; social center of mother and child; child services; center of social-psychological rehabilitation of children; a center of social-psychological rehabilitation of children and young people with functional limitations; center of social-psychological help; center of professional rehabilitation of invalids; center of reintegration of homeless citizens; center of participants of battle actions; center of employment; pension fund and others like that.

Accordingly, the clients of social worker are: children-orphans and the children deprived paternal caring; children with disability; children, who lost parents at implementation of official duties; having many children, incomplete, adopted, of lowincome, dysfunctional families; labor migrants; unemployed persons; participants of battle actions; inwardly moved persons; pensioners and single disabled citizens and others like that. Having regard to the vast spectrum of establishments and clients a social worker can work with one of the tasks of higher educational establishment of education is forming of tolerance among future students as professionally important quality, that represents active social position and psychological readiness to adjusting of the positive co-operating with people or groups of other social, religious, national environment, other views, styles of thinking and behavior.

Taking into account what is marked, the model of forming of tolerance of future social workers in the process of their practical preparation is examined in the article.

Key words: tolerance, professional becoming of social workers, model of forming of tolerance, practical preparation of future social workers.
Постановка проблеми у загальному вигляді. Освітньо-кваліфікаційна характеристика соціального працівника 3 вищою освітою визначає толерантність необхідною складовою частиною діяльності фрахівця, оскільки безумовне прийняття особистості клієнта з усіма його поглядами і переконаннями виступає передумовою побудови співпраці на засадах взаєморозуміння.

Провідною фрормою учбового процесу вищого навчального закладу освіти, яка дає можливість істотної морально-психологічної побудови особистості майбутнього спеціаліста, на наш погляд,
$€$ фрахова практика (від її навчальних до виробничих форм), що зумовлює необхідність створення моделі фрормування толерантності майбутніх соціальних працівників у процесі практичної підготовки.

Аналіз останніх досліджень і публікацій. Толерантність як профресійно важливу якість фахівця, що виявляє свою сутність як здатність сприймати без агресії відмінні від його власних судження, стиль життя, характер поведінки, зовнішність і будь-які інші особливості людей, які його оточують у сорері освітнього простору і соціокультурного середовища, шляхом встановлення 
3 ними відносин довіри, співпраці, компромісу, радості, товариськості, співпереживання та психологічного комфорту, вважають такі сучасні вчені, як: В. Андрущенко, І. Бех, А. Богуш, І. Зязюн, Л. Кондрашова, В. Кравець, В. Кузь, В. Лозова, Ю. Мальований, І. Прокопенко, О. Савченко, О. Сухомлинська, Ю. Тодорцева, Н. Ярмаченко та ін.

Питання підготовки і професійного становлення фрахівців соціальної сфрери розглянуто в працях С. Архипової, Л. Гончого, Л. Гуслякової, Н. Заверіко, А. Капської, І. Козубовської, В. Масленникової, Л. Міщик, В. Сластьоніна, О. Сорочинської, С. Тетерського, С. Чистякової, Б. Шапіро, І. Шарова, Н. Шмельової. Практична підготовка трактується ними як важливий компонент процесу формування системи спеціальних знань, умінь, навичок; прагнення і здатності до самостійного, творчого вирішення професійних завдань; психологічної і соціально-психологічної готовності виконувати професійні обов'язки.

Виділення не вирішених раніше частин загальної проблеми. Незважаючи на достатнє коло проведених досліджень толерантності як профресійно важливої якості фрахівців соціальної сорери та питань їх професійного становлення, проблема фрормування толерантності майбутніх соціальних працівників у процесі практичної підготовки потребує додаткового вивчення.

Мета статті. 3 огляду на зазначене, метою статті $€$ характеристика моделі фрормування толерантності майбутніх соціальних працівників у процесі практичної підготовки.

Виклад основного матеріалу. Толерантність $€$ важливим компонентом професійної компетенції будь-якого працівника сорери «людина-людина», але у зв'язку із зазначеною специфрікою роботи соціального працівника вона $€$ основою його профресійної свідомості. Соціальний працівник у своїй роботі зобов'язаний дотримуватися «Декларації принципів толерантності», що була прийнята Генеральною конференцією ЮНЕСКО 16 листопада 1995 року [3], навіть якщо деякі категорії клієнтів не викликають симпатії фрахівця, а їх політичні, релігійні і національні особливості, поведінкові стереотипи і зовнішність виявляються незвичними.

На нашу думку, толерантність $€$ інтегруючою професійно важливою якістю соціального працівника, без достатнього рівня прояву якої неможлива есрективна взаємодія фрахівця і клієнта. Для ефективного фрормування зазначеної якості необхідне створення відповідних умов іії практичної апробації.

Створюючи модель фрормування толерантності майбутніх соціальних працівників у процесі практичної підготовки, ми виходили з такого розуміння терміна «модель» - «зображення, схема, графрік будь-якого об'єкта, процесу або явища, що використовується як його спрощена заміна» [1, с. 47].

Модель, яку ми пропонуємо, - це своєрідне уявлення, що певним чином ілюструє зразок толерантності і всього того, що пов'язано з формуванням цієї професійно важливої для соціальних працівників якості у взаємозв'язку, взаємозалежності і взаємозумовленості. У нашому випадку модель, яка зображена на рис. 1, фріксує проєктований процес формування толерантності майбутніх соціальних працівників у процесі їх практичної підготовки.

Як бачимо, метою запропонованої моделі $€$ форомуання толерантності майбутніх соціальних працівників у процесі практичної підготовки на підставі реалізації трьох педагогічних умов.

Першою педагогічною умовою фрормування толерантності майбутніх соціальних працівників $€$ діагностика розвитку компонентів толерантності, яка передбачає використання комплексу тестових методик, що дасть можливість студентам визначити власний рівень толерантності та забезпечить поетапне формування ціннісних орієнтацій, умінь і навичок толерантної взаємодії.

Другою умовою є організація фрахової практики за принципами поступового просресійного ускладнення практичної діяльності, інтеграції,

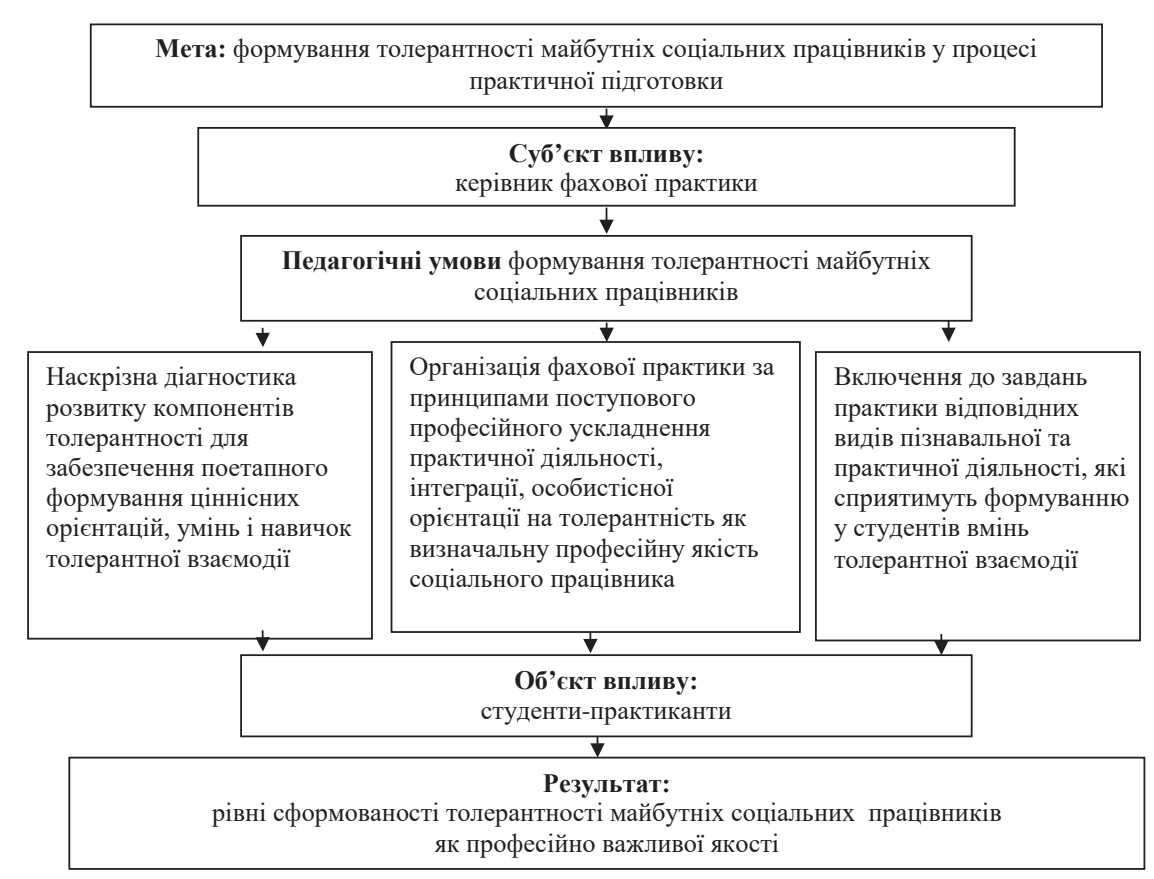

Рис. 1. Модель формування толерантності майбутніх соціальних працівників у процесі практичної підготовки 
особистісної орієнтації на толерантність, що розуміється нами як один із засобів підвищення ефективності формування зазначеної професійно важливої якості особистості соціального працівника.

Третьою педагогічною умовою срормування толерантності майбутніх соціальних працівників є включення до завдань практики відповідних видів пізнавальної та практичної діяльності. Зокрема, таких як: ознайомлення 3 інноваційними формами та методами діяльності соціального працівника з різними категоріями клієнтів; надання допомоги клієнтові для його повноцінного (рівноправного) спілкування із суспільством; допомога людям похилого віку, особам з особливими потребами тощо.

Виконання зазначених видів пізнавальної та практичної діяльності дає змогу студентам ствердитись у власному професійному виборі; переконатися у значущості діяльності соціального працівника для різних суспільних сорер; сорормувати стійку потребу майбутніх спеціалістів у професійному зростанні; оволодіти ідеями й технікою профресійної взаємодії на засадах розуміння та поваги гідності клієнта, терпимого ставлення до його поглядів, стилю мислення, характеру поведінки, дій.

Кожна із запропонованих педагогічних умов, обіймаючи змістовий, смисловий чи технологічний аспекти практичної підготовки, має сприяти пробудженню відповідних компонентів структури толерантності майбутніх соціальних працівників: когнітивного, емоційного і поведінкового.

Когнітивний компонент толерантності розуміється через визнання складності, багатовимірності та різноманіття світу й не зведення цього різноманіття до одноманітності [5, с. 12]. Саме ці аспекти підкреслюються в Декларації принципів толерантності, в якій стверджується, що толерантність - це перш за все «правильне розуміння багатого різноманіття культур світу, фрорм самовираження і способів проявів людської індивідуальності» [3].

Зміст цього компонента визначається специсрікою толерантності як якості майбутнього соціального працівника і має на увазі фріксацію в свідомості майбутнього фрахівця результату оволодіння ним знань про толерантність.

Емоційний компонент толерантності відображає необхідність розгляду емпатії як складника толерантних відносин. Як окремий складник емоційного компонента Г. Крісталл виділяє особливий вид емоційної стійкості - «афективну толерантність». Сутність останньої полягає у здатності долати емоційну напругу, терпимо ставитися до хворобливих переживань, тривоги без того, щоб пригнічувати або спотворювати їх [4].

Інший аспект цього компонента толерантності пов'язаний, на думку С. Братченко, з терпимим ставленням до різних (включаючи яскраві, індивідуальні, незвичні форми) емоційних проявів інших людей. Розвинена асрективна толерантність дає змогу людині краще усвідомлювати як власні емоційні процеси, так і переживання інших людей, не дратуючись і не приписуючи їм негативного змісту [2].

Поведінковий компонент толерантності проявляється під час дії на основі толерантності, тобто цей компонент відображає регуляцію суб'єктом власної дії, що виражається в недопущенні нанесення збитку собі та іншим людям, посиленні особистості іншого суб'єкта (поліпшенні психічного стану, надання можливості вийти зі скрутного становища) [6, с. 9].

Наступним складником моделі (рис. 1) є рівні сорормованості толерантності майбутніх соціальних працівників, якими є:

- високий рівень, що характеризується наявністю у студентів систематичних знань міжнародних документів, що регламентують основні права людини, про допустимість толерантності в межах моральності, про значущість подолання егоцентризму, про шляхи пошуку можливостей узгодження різних думок і позицій. Стійкий характер носить втілення в реальність вибраних альтернатив толерантної взаємодії;

- середній рівень - представлений наявністю знань про зміст міжнародних документів, що відображають основні права людини, про значущість позитивної взаємодії, уміння контролювати себе, але реалізація цих знань на практиці носить ситуативний характер. Виражається прагнення до співчуття, співпереживання, заборони негативних емоцій, узгодженості позицій, критичності у виборі форм поведінки, прояву спокою і доброзичливості до протилежної сторони;

- низький рівень, що характеризується поверхневими знаннями про допустимість толерантності в межах моральності, значущості орієнтації позиції, спрямованої на творення, а не на знищення, про результат власних дій і вчинків. Простежується відсутність прагнення до поповнення відповідних знань і використання їх на практиці. Відсутнє позитивне ставлення до проявів індивідуальності в іншому. Інша думка, позиція не приймаються. Не досить розвиненим є усвідомлення неправомірності примушуючої дії. Відсутня потреба втілення в реальність альтернативних фоорм толерантної поведінки.

Підвищення рівня сорормованості толерантності майбутніх соціальних працівників, на нашу думку, є можливим у процесі практичної підготовки, з огляду на запропоновані педагогічні умови формування зазначеної професійно важливої якості спеціаліста.

Висновки. Отже, охарактеризувавши модель формування толерантності майбутніх соціальних працівників у процесі практичної підготовки, можна зробити такі висновки:

1. Фахова практика студентів спеціальності «Соціальна робота» (від її навчальних до виробничих форм) може виступати провідною фрормою 
навчального процесу вищого навчального закладу освіти, яка дає можливість фрормування толерантності майбутніх соціальних працівників.

2. Педагогічними умовами фрормування толерантності майбутніх соціальних працівників у процесі практичної підготовки є: наскрізна діагностика розвитку компонентів толерантності для забезпечення поетапного фрормування ціннісних орієнтацій, умінь і навичок толерантної взаємодії; організація фрахової практики за принципами поступового профресійного ускладнення практичної діяльності, інтеграції, особистісної орієнтації на толерантність як визначальну професійну якість соціального працівника; включення до завдань практики відповідних видів пізнавальної та практичної діяльності, які сприятимуть фрормуванню у студентів умінь толерантної взаємодії.

3. Рівні особистісного прояву толерантності поділяються на високий, середній та низький. Врахування педагогічних умов фрормування толерантності майбутніх соціальних працівників у процесі практичної підготовки дасть можливість підвищити рівень сорормованості зазначеної професійно важливої якості спеціаліста.
БІБЛІОГРАФІЧНИЙ СПИСОК:

1. Базилевич Н.Г. та ін. Словник термінології з педагогічної майстерності / за ред. Н.М. Тарасевич та ін. Полтава, 1995. С. 47.

2. Братченко С.Л. Межличностный диалог и его основные атрибуты. Психология с человеческим лицом: гуманистическая перспектива в постсоветской психологии. Москва, 1997. С. 201-222.

3. Декларація принципів толерантності. URL: https://zakon.rada.gov.ua/laws/show/995_503 (дата звернення: 13.04.2020).

4. Кристалл Г. Афрорективная толерантность. Журнал практической психологии и психоанализа. 2001. № 3. C. 71-88.

5. Мисходжева Ф.А. Педагогические условия формирования толерантных отношений старшеклассников на основе развития коммуникативной культуры : автореф. дисс. на соискание научной степени канд. пед. наук : спец. 13.00.01 «Общая педагогика, история педагогики и образования». Владикавказ, 2012. С. 12.

6. Тодорцева Ю.В. Формування толерантності майбутніх учителів у процесі професійної підготовки : автореср. дис. на здобуття наукового ступеня канд. пед. наук : спец. 13.00.04 «Теорія і методика професійної освіти». Одеса, 2004. С. 9. 